\title{
Relationships between Socio-demographic Variables and Psychological Empowerment among Members of Fadama User Groups (FUGs) in Kankara Local Community, Katsina State, Nigeria
}

\author{
Aminu Rilwanu ${ }^{1,2}$, Ma'rof Redzuan ${ }^{1}$, Asnarulkhadi Abu-Samah ${ }^{1}$ \\ ${ }^{I}$ Department of Social and Development Science, Faculty of Human Ecology, Universiti Putra Malaysia \\ ${ }^{2}$ Department of Geography, Isa Kaita College of Education, PMB.5007, Dutsin-ma, Katsina State, Nigeria
}

\begin{abstract}
This empirical research was designed to focus on the relationship between Socio-demographic variables and psychological empowerment among Fadama User Groups (FUGs) in Kankara Local Community, Katsina State Nigeria. The total of 285 respondents was selected through random sampling techniques. And the instrument use for data collection was structured questionnaire. The collected data was analyzed by using descriptive statistics and chi-square in cross-tabulation form to describe the respondent background through descriptive analysis. Meanwhile cross tabulation was to find out the relationship between Socio-demographic variables and psychological empowerment among Fadama members. The result shows; there is no significant relationship $(p>0.05)$ between Socio-demographic variables and psychological empowerment. However, the results within the age group (27-39years) in the low level of empowerment have the frequency of 5 with (27.8\%) level of achievement of psychological empowerment. In the moderate level of empowerment, there are 20 with (24.4\%) level of achievement of psychological empowerment among the respondent. Moreover, in the high level, the age involved was 40 with (21.6\%) level of achievement of psychological empowerment among the respondent. Meanwhile, the age group of (40-52years) the same procedure was employed and the results shows there are 12 frequency (66.7\%) reflected the low level of achievement in psychological empowerment and 54 at (65.9\%) was identified as moderate level of achievement, while the 132 at (71.4\%) appeared as the high level of psychological empowerment achievement among the respondents. The last age group was (53-62years) which indicates the low level as 1 at (5.6\%) achievement of psychological empowerment, moderate level of achievement was 8 at (9.8\%) and the high level psychological achievement appeared 13 at (7.0\%). The research concluded that, the respondent background does not have any significant influence toward the achievement of psychological empowerment.
\end{abstract}

Key words: Respondent background, psychological Empowerment and Fadama User Groups (FUGs).

\section{Introduction}

The paper was designed to investigate the relationship between Socio-demographic variables and psychological empowerment among members of Fadama User Groups (FUGs) activities in Kankara local community, Katsina state, Nigeria. The activities of Fadama members are agricultural based activities in connection to rural development. Because agriculture; is the main rural activity and main primary occupation for the rural people to earn a living (Afigbo, 2000). In Nigeria, agricultural production is dominated by small-scale farmers who produce the bulk of the food consumed in the country (Colman, et al, 1996). Their production remains entrenched in the Nigerian economy as it provides raw materials to greater number of small scale agro allied industries (Ibekwe and Adesope, The rural area are the backbone of the nation's economic development (Garba, A.G., 1996, 2010). According to Mohammed (2002) cited in Abu and Asember (2011), fadama area gives high yield per unit area of land, hence generates high income for the user groups. Despite these, in Nigeria the rural areas are the most neglected sector in Nigeria policies. Rural sector was inhabited by the bulk of the nation's population.

The rural people have low purchasing power and standard of living. Harris (1982), citing the World Bank definition of rural development as "... a strategy designed to improve the economic and social life of the specific group of people - the rural Poor." He further identified four major factors that affect the rural poor, one of them is persistent increase and deepening poverty. This and many more are among the factors which draw the attention of the researcher to carry out this research. To find out to what extent the respondents background of Fadama members may be associated with their psychological empowerment in the local community.

Ghai (1988) view Fadama activities as a process of empowering the deprived and excluded people (rural poor); he further stated that rural people may achieve tremendously through Fadama activities and get power to control the Fadama resources psychologically and improve economically. The respondents' 
background was use as the parameter to look in to the Fadama members' psychological changes in empowerment. In line with the above assertion, socio-demographic variable may necessitates the creation of organizations (Fadama User Group activities) for rural poor which are democratic, independent and self-reliant. This is one of the reasons why Fadama activities was created, based on the respondents background the local community may have the achievement of psychological empowerment.

Empowerment is a process by which people, organizations, and communities gain mastry over issues that concern them directly (Rappaport, 1987). It was also highlighted that, Fadama member's activities is an organizational action set-up for the purpose of gaining mastery, understanding, awareness and experience. Similarly, psychological empowerment can be refers to a constructs which integrates people perceptions, personal control, proactive approach of life and critical understanding of the socio-political and economic variables of the environment. Zimmerman, (1995) suggests that organizational empowerment includes process and structures that may enhance Fadama members' skills and experience which can give them support for effective community and social change (i.e., through empowering the Fadama members). And this process may reach the community level through Fadama members working together in an organized and strategically plan way to improve their collective life to achieve whatever they have plan for psychological equilibrium.

The central focus of this paper is to explore the relationships between Socio-demographic variables and the achievement of psychological empowerment by the Fadama members. Zimmerman, (1995) opined that conceptual development of psychological empowerment its' further develops the empowerment theory by explicitly defining a fundamental element necessary for understanding and analysis. The conceptualization of psychological empowerment was presented and rooted firmly in a social action framework that includes community change, capacity building and experience (Keiffer, 1984; Rapparport, 1981; Zimmerman, 1995). Psychological empowerment does not only refer to self-perceptions of competence, but it includes active engagement in one's community and understanding of one's socio-political environment.

Moreover, psychological empowerment may include learning about controlling agents and acting to influence those agents or factors (Zimmerman, Israel, Schulz, and Checkoway, 1992). Thus, psychological empowerment should not only be interpreted as individual action, or the process of promoting one ideology versus another, or a merely intra-psychic phenomenon. But psychological empowerment includes beliefs that goals can be achieved, through awareness, understanding, experience as well as human capital to enhance Fadama members' resourcefulness, any other factors that might enhance one's effort to achieve their set-goals or objectives is vital. Similarly, the purpose of this paper is to use Fadama members' activities in judging the relationship of the respondent's background with the psychological empowerment.

\section{Statement of the problem}

Some of the issues which attract the attention of the researcher were practical issues, like lack of people awareness and involvement. A persistent increase of poverty level among the Fadama members in the local community is another issue. Other issues are theoretical such as lack of research on the matter conducted in the area, as such no available literature found. But notwithstanding, the researcher was able to find some relevant text that can provide guides to the successful completion of his work. Before any advance comment, let us trace the origin of Fadama. The root word FADAMA comes from Hausa language, the dominant tribe of northern Nigeria. It simply refers to a fertile alluvial plain, located along the Nigerian rivers. The word is ordinary used to represent dry season irrigation farming in Nigeria. Blench and Ingawa (2004) define "Fadama" as any flood plains and low lying areas underline by shallow aquifers and found along the Nigeria's river systems.

\section{Research objectives}

As a result of the above problem, the researcher intended to use respondent background and psychological empowerment to examine these issues through the following objectives:

$>$ To examine the respondent background such as age, gender, marital status, educational attainment and income level.

$>$ To explore the relationships between the Socio-demographic variables and psychological empowerment in Fadama activities.

\section{Methodology}

The method used in this paper was descriptive statistics in which Socio-demographic variables was cross tabulated with psychological empowerment. The population and sample was determine using Kreijcie and Morgan, (1970) table; in which 1176 is the population, therefore 285unit are chosen at random as respondents in this research Moreover, the instrument used for data collection was a structured questionnaire. The questionnaire was designed on 4 Likert scale to collect the required information from each respondents. 


\section{Findings and discussion}

The table1 presents the descriptive analyses of the respondents' background. The frequency and percentage of all variables were indicated in addition mean and standard deviation in each category are highlighted that:

Table 1: Background of the respondents $(n=285)$

\begin{tabular}{|c|c|c|c|c|c|c|c|}
\hline Variables & Frequency & Percentage & & $\bar{M}$ & SD & Min. & Max. \\
\hline Age Group & & & & 43.18 & 6.10 & 27 & 62 \\
\hline $27-39$ years & 65 & 22.8 & & & & & \\
\hline 40- 52 years & 198 & 69.5 & & & & & \\
\hline 53years \& above & 22 & 7.7 & & & & & \\
\hline \multicolumn{8}{|l|}{ Gender } \\
\hline Male & 252 & 88.4 & & & & & \\
\hline Female & 33 & 11.6 & & & & & \\
\hline \multicolumn{8}{|l|}{ Marital Status } \\
\hline Single & 2 & 0.7 & & & & & \\
\hline Married & 277 & 97.2 & & & & & \\
\hline Widow/widower & 6 & 2.1 & & & & & \\
\hline \multicolumn{8}{|l|}{ Level of education } \\
\hline Primary & 14 & 4.9 & & & & & \\
\hline Secondary & 95 & 33.3 & & & & & \\
\hline Tertiary & 176 & 61.8 & & & & & \\
\hline Monthly Income (Net) & & 427.47 & 51.95 & 273 & 502 & & \\
\hline 273-349(USD) & 32 & 11.2 & & & & & \\
\hline $350-426$ (USD) & 80 & 28.1 & & & & & \\
\hline 427-502 (USD) & 173 & 60.7 & & & & & \\
\hline
\end{tabular}

The age of the respondents ranges from 27years to 62years, has the (mean=43.18, and $\mathrm{SD}=6.10$ ). Therefore the age group of 40-52years constitutes the majority $(69.5 \%)$, followed by the age group of $27-39$ years $(22.8 \%)$, and the age group of 53-62years $(7.7 \%)$. This finding reveals that age group of (40-52) years are the active population in the local community. This also shows their life style of the group as adults, constituting fathers and mothers; the productive group of any society. They are more of thinking on how to build a strong society viable with the current economic, political, and psychological needs. As such they must struggle for basic needs. This may be the reason why they engaged in the self-help organizations like Fadama User Groups, Women Self- help Groups, Fish Farming User Groups and Fadama Pastoralists User Groups among others. Economically that was the productive or working class. On the other hand, the age group 53-62 years, in Fadama User Groups (FUGs) activities. is the least (7.7\%). This is because they were classified as ageing class. Their skills are mostly use for advising youth adults to participate in the project activities. This finding was supported by Nwosu C.S. et al (2012) cited Emenyonu et al (2010) that majority of the active farmers in Nigeria are in between the age of 27-48 years. The mean age of the farmers was (39years). Nwaru, (2004) assertain that the young adult's farmers are more ready to accept changes and new innovation then the old age farmers in Nigeria.

Gender in this research means the total number of males and females who were involve in the fadama activities. The number of males was $252(88.4 \%)$ and females were $33(11.6 \%)$. This happen because the research area was dominated by Muslim community and in line with the teaching of Islam, women were meant to remain at home to avoid interacting with men. This is one of the reasons that make their male counterpart to dominate must of the economic, social and political development in the area. Another finding conducted in the southern part of Nigeria, by Nwosu, C.S. et al (2012) in his research finding on farmer's activities on fluted pumkin production in Imo state, Nigeria. The finding shows that majority of the farmers were females $(96.70 \%)$. Which is contrary with this research finding on Fadama members activities in (FUGs) Kankara local community, Katsina state Nigeria. This is because there is religious influence on this difference of the result finding between northern and southern Nigeria.

Marital status in this research includes; single, married, widow/widower respondent who were involving in to the Fadama activities. The married respondents were the majority with $277(97.2 \%)$ and the widow/widower was 6 with $(2.1 \%)$ and they are the moderate class. While the minority groups were the single (not married) respondent and they were only 2 with $(0.7 \%)$. The reasons that make the married involvement got the majority were due to the nature of Fadama activities, it's required the active peoples. And those members fall within the age group from 40-52years who were also recorded high under the age category. Why because at this level the people in the local community are more matured thinking of the 
society and how to developed themselves psychologically (empowerment) and the community. Another reason is that the married people have compulsion on them to feed their family (self-reliant). This and many more triggered the married people to get involved in these activities.

Level of education refers to the level at which an individual respondents was able to possess the highest educational qualification before engaging in to Fadama activities. As such the analysis shown that tertiary education has the majority with 176(61.8\%). And the moderate group has the scores of 95(33.3\%), while the minority group were the primary school leavers who were emerged with 14(4.9\%). This happen because most of the local people who attained the tertiary education they have high awareness level on the project activities, in the local community then those who only attend the primary schools. Similar finding conducted in the southern part of Nigeria by Nwosu C.S. (2012) in his finding it indicated that majority of the farmers were educated to the level of secondary school were up to $(31.70 \%)$; while the tertiary level of education were up to $(28.30 \%)$. And $(20.00 \%)$ were educated to primary school level. This result indicated that about $(80.00 \%)$ of the farmers are literate.

Monthly income refers to the amount of income an individual member can earn/get at the end of each month from the Fadama activities only. Therefore, members who are earning (427-502USD) constitutes the majority with $(60.7 \%)$, followed by members who are earning (350-426USD) with $(28.1 \%)$ as the moderate class and members who are earning (273-349USD) with (11.2\%) were the minority in this Fadama activities. This happen because most of the members who were earning (427-502USD) are the group of people who were able to attends the tertiary institutions. Their combine knowledge of western education and Islamic knowledge help them to interact with anybody in the Fadama activities. And these boost their level of social capital as well as increase the level of their awareness, human capital and experience to achieve higher in the empowerment outcomes. Meanwhile, they were able to achieve reasonably in their calculated mean which shows (mean=427.47 and SD=51.95). More over the research was able to discovered that; those people in addition with the above reason they were able to use mixed farming like (Animals rearing and Land cultivation).

\section{Socio-demographic variables and Psychological Empowerment}

Table 2 shows the relationships between Socio-demographic variables and psychological empowerment among the Fadama members.

Table 2: Socio-demographic variables and Psychological Empowerment $(\mathbf{n}=\mathbf{2 8 5})$

\begin{tabular}{|c|c|c|c|c|c|c|c|c|c|c|}
\hline \multirow[b]{3}{*}{ Variable } & \multirow[b]{3}{*}{ Mean } & \multirow[b]{3}{*}{ SD } & \multicolumn{6}{|c|}{ Levels of Psychological Empowerment } & \multirow[t]{3}{*}{$\mathrm{N}$} & \multirow[t]{3}{*}{$\%$} \\
\hline & & & \multicolumn{2}{|c|}{$\operatorname{Low}(5-8.3)$} & \multicolumn{2}{|c|}{ Moderate(8.4-11.7) } & \multicolumn{2}{|c|}{ High(11.8-15) } & & \\
\hline & & & $\mathrm{N}$ & $\%$ & $\mathrm{~N}$ & $\%$ & $\mathrm{~N}$ & $\%$ & & \\
\hline Age & 43.18 & 6.10 & & & & & & & & \\
\hline $27-39$ & & & 05 & 7.7 & 20 & 30.8 & 40 & 61.5 & 65 & 100 \\
\hline $40-52$ & & & 12 & 6.1 & 54 & 27.3 & 132 & 66.7 & 198 & 100 \\
\hline $53-62$ & & & 01 & 4.5 & 08 & 36.4 & 13 & 59.1 & 22 & 100 \\
\hline Total & & & 18 & 6.3 & 82 & 28.8 & 185 & 64.9 & 285 & 100 \\
\hline \multicolumn{11}{|l|}{ Gender } \\
\hline Male & & & 16 & 6.3 & 72 & 28.6 & 164 & 65.1 & 252 & 100 \\
\hline Female & & & 02 & 6.1 & 10 & 30.3 & 21 & 63.6 & 33 & 100 \\
\hline Total & & & 18 & 6.3 & 82 & 28.8 & 185 & 64.9 & 285 & 100 \\
\hline \multicolumn{11}{|l|}{ Marital status } \\
\hline Single & & & 0 & .0 & 0 & .0 & 2 & 100 & 02 & 100 \\
\hline Married & & & 18 & 6.5 & 80 & 28.9 & 179 & 64.6 & 277 & 100 \\
\hline Widow/widower & & & 0 & .0 & 2 & 33.3 & 4 & 66.7 & 06 & 100 \\
\hline Total & & & 18 & 6.3 & 82 & 28.8 & 185 & 64.9 & 285 & 100 \\
\hline \multicolumn{11}{|l|}{ Level of education } \\
\hline Primary & & & 0 & .0 & 5 & 35.7 & 9 & 64.3 & 14 & 100 \\
\hline Secondary & & & 07 & 7.4 & 29 & 30.5 & 59 & 62.1 & 95 & 100 \\
\hline Tertiary & & & 11 & 6.3 & 48 & 27.3 & 117 & 66.5 & 176 & 100 \\
\hline Total & & & 18 & 6.3 & 82 & 28.8 & 185 & 64.9 & 285 & 100 \\
\hline Monthly income & $\begin{array}{l}427.4 \\
7\end{array}$ & 51.9 & & & & & & & & \\
\hline $273-349$ & & & 2 & 6.3 & 11 & 34.4 & 19 & 59.4 & 32 & 100 \\
\hline $350-426$ & & & 4 & 5.0 & 22 & 27.5 & 54 & 67.5 & 80 & 100 \\
\hline
\end{tabular}


Relationships between Socio-demographic Variables and Psychological Empowerment among

\begin{tabular}{lllllllll}
$427-502$ & 12 & 6.9 & 49 & 28.3 & 112 & 64.7 & 173 & 100 \\
Total & 18 & 6.3 & 82 & 28.8 & 185 & 64.9 & 285 & 100 \\
\hline
\end{tabular}

Source: Field work, 2013.

The above table illustrated that the age group of (27-39years) in the lower level has the frequency of 5(7.7\%) and the moderate level is 20(30.8\%) while the high level of age involvement was 40 with (61.5\%). Similarly by comparing with the whole mean of ages it shows that 40 with (21.6\%) appeared as the high level of respondent involvement in the Fadama activities in the local community. Meanwhile, the age group of (40-52years) was further classified in to low, moderate and high level and the results shows that: 12(6.1\%) was under the low level and $54(27.3 \%)$ was identified as moderate level while the 132 with $(66.7 \%)$ was appeared as the high level of respondents in Fadama activities. The next age group is (53-62years); this age group was also been analyzed based on low, moderate and high. And the analysis results appeared like this low level was 1(4.5\%) and the moderate level reflected with $8(36.4 \%)$ and the high level appeared with $13(59.1 \%)$.

Gender was the next variable to analyzed, based on male and female involvement in the Fadama activities in Kankara local community. In the male category, 16(6.3\%) appeared as the low level of Fadama activities in the local community, while 72 with $(28.6 \%)$ was reflected in the moderate level and 164 with $(65.1 \%)$ was appeared in the high level of Fadama activities in the local community. Moreover, in the female category, the result shows that; 2(6.1\%) was reflecting the low level of females involvement in the Fadama activities and 10(30.3\%) was reflecting the moderate level of respondents involvement in the Fadama activities. Similarly, 21 with $(63.6 \%)$ are indicating the high level of respondent involvement in the Fadama User Groups (FUGs) activities in Kankara local community.

Marital status was also classified as low, moderate and high based on the respondents' background. The single respondents was appeared 0 with $(.0 \%)$ under the low level of respondents involvement. And 0 with $(.0 \%)$ was appeared again in the moderate level; this shows that respondents were more of getting involve when they are married then those who are single. But it shows the single respondents appeared in the high level of involvement with 2 frequency and (100\%). Then the category of married peoples results shows that the low level has appeared with 18(6.5\%), while the moderate level reflected $80(28.9 \%)$ moreover, the high level of respondents' involvement indicated $179(64.6 \%)$ among the respondents background in the Fadama activities. In addition to that; widow/widowers were also among the respondent, in which the $0(.0 \%)$ indicated the low level of widows involvement in the Fadama activities. Then the result of 2(33.3\%) reflected the moderate level of respondents involvement in this project activities. Meanwhile, the sum of 4 with $(66.7 \%)$ indicated the high level of Fadama members' activities in the local community.

The research work also considered educational level to identify the level of respondents' background involvement in Fadama activities through categorizing the educational group in to low, moderate and high. The primary category for the low level were 0 at $(.0 \%)$ while the moderate level were 5 with (35.7\%), and the high level of the respondents background emerged with 9 with $(64.3 \%)$. Similarly, the secondary category of the respondent has the low level of $7(7.4 \%)$ and the moderate level has 29 with $(30.5 \%)$; moreover the high level of the respondent in this category has 59 with (62.1\%). In addition to that, the category of tertiary level of education respondent start from the low level with 11(6.3\%) and 48 with (27.3\%) for the moderate level among the respondents belong to the tertiary category. While the high level of respondent that belong to the tertiary category of education were 117 with $(66.5 \%)$. This shows that the tertiary category get the majority of the respondent involvement in the Fadama project activities in Kankara local community.

Income levels, is another variable the research work wanted to examine for determining the respondents background of the Fadama members in the successful achievement of psychological empowerment. This category was also classified in to low, moderate and high based on the respondent involvement in the Fadama project activities. The low level of the respondent from the (273-349) income earners' has the frequency level of 2 with $(6.3 \%)$, and the frequency level of 11 with $(34.4 \%)$ that fall within the moderate level; while 19 with $(59.4 \%)$ belong to the high level of the respondent background who get involved in the Fadama User Groups activities in the local community. Meanwhile, the next income earners were the group of (350-426) who were also classified in to low, moderate and high. The low level in this group has the frequency number of 4 with $(5.0 \%)$ and the moderate level of frequency number of 22 with $(27.5 \%)$. While the high level among this income earners emerged with 54 frequency number with (67.5\%). In addition to that we have the group of (427-502) who were also classified in to low, moderate and high level. The low level of respondent frequency was 12 with $(6.9 \%)$, while the moderate level has the frequency number of $49(28.8 \%)$ and the high level of frequency with $185(64.9 \%)$. From the mean value of (mean 427.47 and SD of 51.9) the respondent background shows that the high level is more prone to the achievement of high psychological empowerment then the lower level among the respondents of the Fadama users association, in Kankara local community.

\section{Summary and Conclusion}


The above tables 1, 2 and 3 summarized the whole activities carried out by the Fadama user groups (FUGs) through respondent background analysis, level of the respondent background and the level of the achievement of psychological empowerment among the respondent members' of Fadama User Groups (FUGs) in Kankara local community, Katsina State-Nigeria. This analysis was done by employing the descriptive statistics and chi-square analysis to create cross tabulation table. And the objectives of the research were achieved successfully. And the finding was supported by work of Ahmed Shukri Abdul Hamid (2008), where he highlighted that in order to achieve empowerment; it requires active participation from the community members'. That is why in table three cross tabulation indicated that people at the low level in background can even achieve higher in the psychological empowerment when you look at the level of psychological empowerment distribution based on percentage. Therefore, the achievement of psychological empowerment does not have any significant relationship with the respondent background in the Fadama activities, the classification and distribution is only by the active involvement in to the project activities. This finding was supported by Zimmerman in his theory of Psychological Empowerment (PE), He opined that; psychological empowerment is not only based on self-perceptions of competence; but it includes active engagement in one's life or community and an understanding of one's socio-political environment. PE-also includes learning about controlling agents and acting to influence those agents in to actions (Zimmerman, Israel, Schulz, \& Checkoway, 1992). This is the focus of the research paper, to find out to what extent the respondent background role can influence the psychological empowerment among the members' of Fadama User Groups (FUGs) in Kankara local community, Katsina State, Nigeria.

\section{Recommendation}

In line with this study the researcher is recommending that the next research should pay attention on women participation in the project activities. And Youth also should be encouraged in these participation activities for community development.

\section{References}

[1]. Abu, O. and Asember, D.J. (2011) Opportunities for smallholder Spinach farmers in Nigeria: a Profit efficiency analysis. Journal of Economics, 2(2): 75-79(2011)

[2]. Adesoji S.A., Farinde A.J., Ajayi O.A. (2006). An Assessment of the TrainingNeeds of Fadama Farmers for Future Agricultural Extension WorkDevelopment in Osun State, Nigeria. Journal of Applied Scinces. 6(15): 3089-3095.

[3]. Afigbo, A.E. (2000) “Towards Understanding Community Development through Self-Help: The Nigerian Example." Policy and Contending issues in Nigerian National Development Strategy, John Jacob's Classic Publishers Ltd, Enugu.

[4]. Agbola, T. (1988). "The participation of the Rural Poor in Rural Development: A Theoretical Construct", NigeriaJournal of Economic and Social Studies. Vol. 30, No.5, pp. 167-177.

[5]. Ahmad Shukri Abdul Hamid (2008) Empowering the Marginalized: the role of social capital andCivil society. In Fuziah Shaffie and Rozita Yusoff.(eds) (2008). University UtaraMalaysia.

[6]. Annon, T.H. (2008) Rural poverty in Nigeria; Rural Poverty Portal Nigeria downloaded from http//www.globalaging.org/index. Retrieved date, jan27, 2009.

[7]. Blench, R. and Ingawa, S.A. (2004) A Practical Guide for Fadama Development II-Facilitators on Conflict Analysis and Management. The World Bank Project Coordinating Unit,Handbook.

[8]. Cohen, J.C. \& Uphoff, N.T. (1977) Rural Participation: Concept and Measures for project design, Implementation and evaluation. Monograph No. 2, New York: RuralDevelopment Committee, Centre of International studies, Cornell University.

[9]. Colman, D., and Okorie, A., (1998) The effect of Structural adjustment on the Nigerian agricultural export sector. Journal of International Development 10(3): 341-355.

[10]. Dauda, T.O, Saka, J.O., and Salahu, B.F. (2009) An assessment on the role of irrigation farming in the millennium development goals; institute of agriculture research and training, Obafemi Awolowo University Ibadan, Nigeria.

[11]. Emenyonu CA, MA Odii, DO Ohajianya, A Henri-Ukoha, SC Onyemauwa, GN Ben-Chendo,: OU Munonye (2010). Effects of Waste Water Use on Vegetable Crop Production in Imo State, Nigeria. Researcher. 2(10): 47-56

[12]. Garba, A.G. (1996) What can we learn from Nigerian's experience with the World Bank's with growth programme, proceedings of the Nigerian Economic Society 1996 Annual Conference, Lagos.

[13]. Ghai, D. (1988) "Participatory development: some perspectives from grassroots experiences", Discussion Paper No. 5, Geneva: UNRISED:

[14]. Harris, John. (1982). General Introduction in Rural Development: Theories of Peasant Economy and Agrarian Change. Edited by John Harris. London: Hutchinson University Library.

[15]. Ibekwe UC, OM Adesope (2010). Analysis of dry season vegetable production in Owerri West Local Government Area of Imo State, Nigeria. J. Dev. Agric. Econ., 2(6): 245-249,

[16]. Keiffer, C. (1984). Citizen empowerment: A developmental perspective. Prevention in Human Services, 3(16), 9-35.

[17]. Krejcie and Morgan, (1970) "determining the size of population sample by using random sample table. Research Method in Education ( $5^{\text {th }}$ edition); published in USA andCanada by Routledge falmer (2002) revised edition.

[18]. Nwachukwu IN, CE Onyenweaku (2009). Allocative Efficiency among Fadama Telfairia Production in Imo State Nigeria. Online at http://mpra.ub.uni-muenchen.de/27249/ MPRA Paper No. 27249, posted 07. December 2010 / 11:46

[19]. Nwaru JC (2004). "Rural Credit Markets and Arable Crop Production in Imo State of Nigeria", Ph. D. Dissertation, Department of Agricultural Economics, Michael Okpara University of Agriculture, Umudike, Nigeria.

[20]. Nwosu C.S., Onyeneke R. U. and Okoli V. B.N., (2012) Socio-economic determinants of fluted Pumpkin leaf (telferia occidentalis) production in Ezinihitte Mbaise local government area of Imo state, Nigeria. Agricultural Science Research Journal Vol. 2(6) pp. $355-361$, June 2012 
[21]. Rappaport, J. (1981) In Praise of Paradox: A Social Policy of Empowerment Over Prevention, American Journal of Community Psychology, 9:1 (1981:Feb.) p.1

[22]. Rappoport, J. (1987) Terms of Empowerment /Exemplars of Prevention: Toward a Theory for Community Psychology. American Journals of Community Psychology, 15(2), 121-143.

[23]. Steve, O. and Williams, O. (2012) Community Self-Help Projects and Rural Development in Ohafia Local Government area. Journal of Sustainable Development in Africa, Vol.14,(4). 2012.

[24]. Udoye, E. E. (1985). "Inter-Community Co-operation in Rural Development in Idemili Local Government Area of Nigeria"( Necessity, Problems and Prospects)(M.Sc. Thesis Unpublished).

[25]. Zimmmerman, M.A., Israel, B.A.; Schulz, A.J.; Checkoway, B.N. (1992) Further Explorations in Empowerment Theory: An empirical analysis of Psychological Empowerment. American Journal of Community Psychology, 20(6), 707-727.

[26]. Zimmerman, M.A. (1995) Psychological Empowerment: Issues and Illustrations, American Journal of Community Psychology, Vol. 23, No. 5, 1995 